\title{
A differential Response of Physic Nut Genotypes Regarding Phosphorus Absorption and Utilization is Evidenced by a Comprehensive Nutrition Efficiency Analysis
}

\author{
José Francisco Teixeira do Amaral ${ }^{1}$, Lima Deleon Martins ${ }^{1}$, Bruno Galvêas Laviola ${ }^{2}$, Leonardo Fardim Christro ${ }^{1}$, \\ Marcelo Antonio Tomaz ${ }^{1}$, Wagner Nunes Rodrigues ${ }^{1}$ \\ ${ }^{1}$ Universidade Federal do Espírito Santo, Centro de Ciências Agrárias, Departamento de Engenharia Rural, \\ Alegre, ES, Brazil \\ ${ }^{2}$ Embrapa Agroenergia, Parque Estação Biológica, Brasília, DF, Brazil \\ Correspondence: José Francisco Teixeira do Amaral, Universidade Federal do Espírito Santo, Centro de Ciências \\ Agrárias, Departamento de Engenharia Rural, Alegre, ES, Brazil. Tel: 55-283-552-8629. E-mail: \\ jfamaral@cca.ufes.br
}

Received: July 26, 2012 Accepted: August 23, 2012 Online Published: November 15, 2012

doi:10.5539/jas.v4n12p164 URL: http://dx.doi.org/10.5539/jas.v4n12p164

\begin{abstract}
The objective of this study was to evaluate the nutritional efficiency of phosphorus in physic nut (Jatropha curcas L.) genotypes, under controlled conditions. The experiment was arranged in a randomized block design, in a factorial scheme $10 \times 2$, using ten physic nut genotypes, two levels of phosphorus available in the soil (10 and $60 \mathrm{mg} \mathrm{dm}^{-3}$ ), and four replications. Cultivation consisted of a period of 100 days, with vegetative growth being evaluated in each experimental plot, with the dry matter mass values, phosphorus contents in the vegetative parts, nutritional efficiency indices, and alpha parameter also being obtained. The results show that the physic nut genotypes present greater vegetative growth, dry matter mass accumulation, $\mathrm{P}$ content, absorption efficiency and translocation at the high level of phosphorus available in the soil. Genotype CNPAE-C2 is the most efficient and responsive to phosphoric fertilization.
\end{abstract}

Keywords: vegetative growth, mineral nutrition, alpha parameter

\section{Introduction}

The search for sustainable development has been occurring at an accelerated rate on the past decades, through the investigation of viable alternatives to achieve a development that can also generate profitability.

Over the past few years, a growing concern over environmental issues has been observed around the world. The concern with the limited fossil oil reserves and the climate change caused by the emission from its combustion have led the search for alternatives. One important alternative that have been studied is the agriculture focused on the production of bioenergy (Falasca et al., 2010). Within this context, the cultivation of oil plants such as the physic nut (Jatropha curcas L.) have been growing in importance, aiming at the production of vegetal oil used in the manufacture of biodiesel.

Phosphorus (P) is the nutrient that limits the biomass production of plant the most in tropical soils (Novais et al., 2007; Wright et al., 2011; Oladiran et al., 2012). In Brazil, due to the source material and the strong interaction of soil with this nutrient, the use of phosphate fertilizers is recurrent, resulting in increased production costs (Raij, 1991; Resende et al., 2007; Reis et al., 2010; Reis et al., 2011).

In the case of physic nut, this nutrient is the fourth most accumulated in the fruits, so the harvest draws a considerable amount of this nutrient from the area, increasing the need for its replacement with the fertilization to minimize the soil depletion over the years of cultivation (Laviola \& Dias, 2008).

In this condition, due the peculiarities of $\mathrm{P}$, the use of genotypes adapted to growing in conditions with lower levels of available $P$ in the soil becomes a valuable alternative to agricultural crop (Fageria \& Baligar, 1997). Therefore, the search for information about the reaction of physic nut genotypes grown under different $\mathrm{P}$ supply is essential to identify genotypes able to provide a better development in tropical soils with limited supply of this nutrient, and 
also to identify genotypes that respond better to the fertilization, allowing better planning and management of the agricultural activity.

According to Fageria (1998), numerous studies indicate genetic variation in relation to the nutritional efficiency of phosphorus in genotypes of the same species, which suggests the need to discriminate genotypes that can be efficient in the utilization of $\mathrm{P}$ in order to cultivate them in soils with low levels of this nutrient.

The aim of this study was to evaluate the nutritional efficiency of $\mathrm{P}$ in genotypes of physic nut, in controlled environment.

\section{Material and Methods}

\subsection{Description of the Study Area and Plant Material}

The experiment was conducted under greenhouse conditions in the experimental area of the Centro de Ciências Agrárias of the Universidade Federal do Espírito Santo (CCA-UFES), in Alegre, ES, with coordinates of $20^{\circ} 45^{\prime} \mathrm{S}$ latitude and $41^{\circ} 33^{\prime} \mathrm{W}$ longitude, and an average altitude of 277.41 meters, from December 2010 to February 2011.

The physic nut seeds (half-sib families) used in this study were provided by germplasm bank from Embrapa Agroenergia (harvested in 2010), and processed by removing the immature and damaged seeds. The seeds were packaged and stored in the refrigerator $\left(3^{\circ} \mathrm{C}\right)$ until use, with their water content being maintained between $10-12 \%$.

The seeds were sown in plastic pots containing $10 \mathrm{dm}^{3}$ of soil collected at a depth of $20-40 \mathrm{~cm}$, with the first $20 \mathrm{~cm}$ of the soil being discarded to reduce the effect of the organic matter present on the surface layer. A soil sample was sent to the laboratory for chemistry and physics analyses, according to Embrapa (1997) (Table 1). The soil was characterized as a clayey Red-yellow Latosol-LVA arg (Embrapa, 2006).

Table 1. Physical and chemical attributes of the soil used in the study

\begin{tabular}{cr}
\hline Attributes & LVAarg \\
\hline Sand $\left(\mathrm{g} \mathrm{kg}^{-1}\right)$ & 552.40 \\
Silt $\left(\mathrm{g} \mathrm{kg}^{-1}\right)$ & 43.60 \\
Clay $\left(\mathrm{g} \mathrm{kg}^{-1}\right)$ & 403.40 \\
Soil density $\left(\mathrm{kg} \mathrm{dm}^{-3}\right)$ & 1.20 \\
$\mathrm{pH}$ & 5.40 \\
$\mathrm{P}\left(\mathrm{mg} \mathrm{dm}^{-3}\right)$ & 2.00 \\
$\mathrm{~K}\left(\mathrm{mg} \mathrm{dm}^{-3}\right)$ & 93.00 \\
$\mathrm{Ca}\left(\mathrm{cmol}_{\mathrm{c}} \mathrm{dm}^{-3}\right)$ & 1.70 \\
$\mathrm{Mg}\left(\mathrm{cmol}_{\mathrm{c}} \mathrm{dm}^{-3}\right)$ & 1.10 \\
$\mathrm{Al}\left(\mathrm{cmol}_{\mathrm{c}} \mathrm{dm}^{-3}\right)$ & 0.00 \\
$\mathrm{H}+\mathrm{Al}\left(\mathrm{cmol}_{\mathrm{c}} \mathrm{dm}^{-3}\right)$ & 2.10 \\
Sum of bases $\left(\mathrm{cmol}_{\mathrm{c}} \mathrm{dm}^{-3}\right)$ & 3.37 \\
CTC potential $\left(\mathrm{cmol}_{\mathrm{c}} \mathrm{dm}^{-3}\right)$ & 5.45 \\
CTC effective $\left(\mathrm{cmol}_{\mathrm{c}} \mathrm{dm}^{-3}\right)$ & 3.37 \\
Base saturation $(\%)$ & 61.80 \\
\hline
\end{tabular}

\subsection{Experimental Design and Conduct of the Study}

The experiment was arranged in a randomized block design, in a factorial scheme $10 \times 2$, with ten physic nut genotypes from different regions of Brazil (Paraíso, Jales, CNPAE-C2, G2, 167, 200, 210, 315, 1501, and 08001) and two levels of available phosphorus in the soil $\left(10\right.$ and $\left.60 \mathrm{mg} \mathrm{dm}^{-3}\right)$ (Laviola \& Dias, 2008), with four replications. Four seeds were sown per pot and, after germination, when the seedlings were approximately 7 inches, each experimental plot was thinned to one plant per pot. 
Fertilization was performed according to recommendation for controlled environmental studies (Novais et al., 1991). Fertilization with nitrogen and potassium was performed in four cover applications, the first at 20 days after sowing, and the others, at an interval of 20 days. In all fertilizations, the nutrients were supplied via p.a. salts $\left(\mathrm{KNO}_{3}, \mathrm{KH}_{2} \mathrm{PO}_{4}, \mathrm{NH}_{4} \mathrm{NO}_{3}\right.$, and $\left.\mathrm{CaHPO}_{4}\right)$, seeking to establish the nutritional balance of the soil.

To determine phosphoric fertilization which would provide the levels of phosphorus available in the soil (10 and $60 \mathrm{mg} \mathrm{dm}^{-3}$ ), a curve for P availability was made according to methodology proposed by Machado et al. (2011). Based on the curve of $\mathrm{P}$ availability in the soil, phosphorus fertilization was performed before planting, using a solution with $\mathrm{KH}_{2} \mathrm{PO}_{4}$ salt diluted in water, mixed in the entire volume of soil, with 0.22 and $1.75 \mathrm{~g} \mathrm{dm}^{-3}$ being respectively applied at high and low levels to provide the desired P levels $\left(10\right.$ and $\left.60 \mathrm{mg} \mathrm{dm}^{-3}\right)$ in the soil solution.

Irrigation was conducted by maintaining the soil moisture throughout the experiment at $60 \%$ of the total pore volume, obtained by particle density and soil density determination using the cylinder method, according to Embrapa (1997).

\subsection{Evaluation of the Study and Calculate Indices}

After 100 days of cultivation, evaluations were carried out in each experimental unit to measure: plant height $(\mathrm{cm})$, stem diameter $(\mathrm{mm})$, leaf number, leaf area $\left(\mathrm{cm}^{2}\right.$ per plant), root volume $\left(\mathrm{cm}^{3}\right.$ per plant) and root dry matter (RDM), aerial part dry matter (ADM) and total dry matter (TDM), in grams per plant. Plant height was measured by using a graded ruler and stem diameter at the stem base with a digital caliper. Leaf area was quantified in the laboratory, using a leaf area integrator model LI 3100 from LICOR.

The stems were cut at the soil level and the leaves were removed manually to obtain dry matter. The roots were extracted from the soil and washed in water, and their volume obtained by using a measuring cylinder. Vegetal material (leaves, stems, and roots) was placed separately in paper bags and dried in an oven with forced air circulation at $60^{\circ} \mathrm{C}$, until constant weight.

After drying, the plant material was weighed using an analytical precision balance and ground separately in a Wiley type mill, for subsequent quantification of the level and content of P. Phosphorus concentrations were determined after digestion of the plant material in a nitric-perchloric acid solution (Embrapa, 1997).

The following indices were calculated for dry matter and nutrient content in the plant: (a) absorption efficiency = (total nutrient content in the plant)/(root dry matter), according to Swiader et al. (1994), (b) translocation efficiency $=[($ nutrient content in the aerial part $) /($ total nutrient content in the plant $)] \times 100$, according to Li et al. (1991), (c) utilization efficiency $=(\text { total dry matter })^{2} /($ total nutrient content in the plant $)$, according to Siddiqi and Glass (1981).

The response to phosphoric fertilization was estimated by the criteria proposed by Ciat (1978), based on determination of the $\alpha$ parameter, where:

$$
\alpha_{\text {parameter }}=\frac{\left(A D M P_{2}-A D M P\right)_{1}}{P_{2}-P_{1}}
$$

where,

ADM: aerial part dry matter $(\mathrm{g}), \mathrm{P}_{1}$ : low level of available $\mathrm{P}$ in the soil $\left(10 \mathrm{mg} \mathrm{dm}^{-3}\right), \mathrm{P}_{2}$ : high level of $\mathrm{P}$ available in the soil $\left(60 \mathrm{mg} \mathrm{dm}^{-3}\right.$ of $\left.\mathrm{P}_{2} \mathrm{O}_{5}\right)$.

Dry matter production of the aerial part at the lowest $\mathrm{P}$ level and the $\alpha$ value results for each genotype were displayed in quadrants. The genotypes were classified into four groups: ER-efficient and responsive genotypes, ENR-efficient and non responsive genotypes; NER-non efficient and responsive genotypes, and NENR-non efficient and non responsive genotypes.

\subsection{Statistical Analysis}

The data were subjected to variance analysis ( $\mathrm{P} \leq 0.05)$, using the statistical software SISVAR (Ferreira, 2008). When the variation sources were significant, the Tukey test $(\mathrm{P} \leq 0.05)$ was used to compare the levels of available phosphorus in the soil for each genotype, and the Scott-Knott test $(\mathrm{P} \leq 0.05)$ was used to compare the genotypes within each level of available phosphorus in soil.

\section{Results and Discussion}

\subsection{Phosphorus Levels Influence the Growth the Physic Nut}

The variance analysis $(\mathrm{P} \leq 0.05)$ revealed a significant interaction between genotypes and phosphorus levels. In general, when comparing the $\mathrm{P}$ levels for each genotype, it could be observed that the higher means for plant height, 
stem diameter, leaf area, root volume, aerial part dry mass, root dry matter, phosphorus content in the aerial part, root and total content were obtained at the high level of available phosphorus in the soil (Tables 2, 3 and 4).

The adequate supply of $\mathrm{P}$ in the soil promotes cell division and growth, which explains the higher means for the variables related to the growth. This effect can enhance the photosynthesis and respiration suggesting a higher production of dry matter (Novais et al., 2007).

According to Lana et al. (2006), high concentrations of $\mathrm{P}$ in the soil promote the production of biomass due the increase of the growth rate, biomass partitioning between roots and shoots, and the uptake rate of $\mathrm{P}$ per root unit.

Due to the peculiarities of the Brazilian soils, about their interaction with $\mathrm{P}$, there are recurring reports that the $\mathrm{P}$ content in the vegetative parts of plants rises as its availability in the soil grows, due to the difficulty of fully saturating those soils with this nutrient (Novais et al., 2007).

Table 2. Means for plant height (PH), stem diameter (SD), leaf area (LA) and root volume (RV) of physic nut genotypes cultivated in soils with two $\mathrm{P}$ levels $\left(10\right.$ and $\left.60 \mathrm{mg} \mathrm{dm}^{-3}\right)$, respectively, $\mathrm{P}_{1}$ and $\mathrm{P}_{2}$

\begin{tabular}{|c|c|c|c|c|c|c|c|c|}
\hline \multirow{2}{*}{ Genotypes } & \multicolumn{2}{|c|}{$\mathrm{PH}$} & \multicolumn{2}{|c|}{ SD } & \multicolumn{2}{|c|}{ LA } & \multicolumn{2}{|c|}{$\mathrm{RV}$} \\
\hline & $\mathrm{P}_{1}$ & $\mathrm{P}_{2}$ & $\mathrm{P}_{1}$ & $\mathrm{P}_{2}$ & $\mathrm{P}_{1}$ & $\mathrm{P}_{2}$ & $\mathrm{P}_{1}$ & $\mathrm{P}_{2}$ \\
\hline $\mathrm{G} 2$ & $48.0 \mathrm{~b} \mathrm{~A}$ & 45.7 e $B$ & $25.5 \mathrm{c} \mathrm{A}$ & $26.2 \mathrm{c} \mathrm{A}$ & $2156.00 \mathrm{~g} \mathrm{~B}$ & $2369.75 \mathrm{~g} \mathrm{~A}$ & $82.50 \mathrm{c} \mathrm{B}$ & $131.72 \mathrm{aA}$ \\
\hline 1501 & $47.0 \mathrm{~b} \mathrm{~A}$ & $42.2 \mathrm{fB}$ & $25.5 \mathrm{c} \mathrm{B}$ & $29.5 \mathrm{aA}$ & $2766.50 \mathrm{~dB}$ & $3448.50 \mathrm{dA}$ & $105.00 \mathrm{~b} \mathrm{~B}$ & $142.50 \mathrm{aA}$ \\
\hline 167 & $48.0 \mathrm{~b} \mathrm{~A}$ & $48.7 \mathrm{c} \mathrm{A}$ & $26.7 \mathrm{~b} \mathrm{~B}$ & $28.7 \mathrm{aA}$ & $2775.00 \mathrm{~d} B$ & 3212.75 e A & 80.00 c B & $132.50 \mathrm{aA}$ \\
\hline 315 & $49.0 \mathrm{~b} \mathrm{~A}$ & $50.5 \mathrm{~b} \mathrm{~A}$ & $29.0 \mathrm{aA}$ & $29.0 \mathrm{aA}$ & 3215.00 a B & 3521.75 c A & $120.00 \mathrm{aA}$ & $111.25 \mathrm{~b} \mathrm{~A}$ \\
\hline 210 & $47.7 \mathrm{~b} \mathrm{~A}$ & $47.5 \mathrm{~d} \mathrm{~A}$ & $26.7 \mathrm{~b} \mathrm{~B}$ & $30.0 \mathrm{aA}$ & 2609.75 e B & $3439.25 \mathrm{~d} \mathrm{~A}$ & 101.25 b B & $121.25 \mathrm{~b} \mathrm{~A}$ \\
\hline 200 & $48.5 \mathrm{~b} \mathrm{~B}$ & $51.5 \mathrm{~b} \mathrm{~A}$ & $27.0 \mathrm{~b} \mathrm{~A}$ & $28.0 \mathrm{~b} \mathrm{~A}$ & $2332.75 \mathrm{fB}$ & $3051.00 \mathrm{fA}$ & $108.25 \mathrm{~b} \mathrm{~B}$ & $130.00 \mathrm{aA}$ \\
\hline 08001 & $47.7 \mathrm{~b} \mathrm{~A}$ & 45.7 e $B$ & $27.0 \mathrm{~b} \mathrm{~A}$ & $27.0 \mathrm{c} \mathrm{A}$ & $2382.75 \mathrm{fA}$ & $2382.50 \mathrm{~g} \mathrm{~A}$ & 83.25 c B & $95.00 \mathrm{c} \mathrm{A}$ \\
\hline Paraíso & $50.7 \mathrm{aA}$ & $47.2 \mathrm{~d} \mathrm{~B}$ & $26.0 \mathrm{~b} \mathrm{~B}$ & $27.7 \mathrm{~b} \mathrm{~A}$ & 2866.75 c B & $3729.25 \mathrm{aA}$ & $105.00 \mathrm{~b} \mathrm{~B}$ & $120.00 \mathrm{~b} \mathrm{~A}$ \\
\hline CNPAE-C2 & $52.2 \mathrm{a} \mathrm{B}$ & $54.2 \mathrm{aA}$ & $26.7 \mathrm{~b} \mathrm{~B}$ & $28.0 \mathrm{~b} \mathrm{~A}$ & 2954.00 b B & $3561.50 \mathrm{c} \mathrm{A}$ & $96.50 \mathrm{~b} \mathrm{~B}$ & $120.00 \mathrm{~b} \mathrm{~A}$ \\
\hline Jales & $52.0 \mathrm{aA}$ & $49.2 \mathrm{c} \mathrm{B}$ & $25.7 \mathrm{c} \mathrm{B}$ & $27.7 \mathrm{~b} \mathrm{~A}$ & $2762.25 \mathrm{~d} \mathrm{~B}$ & $3651.50 \mathrm{~b} \mathrm{~A}$ & $112.25 \mathrm{aA}$ & $105.00 \mathrm{c} \mathrm{A}$ \\
\hline
\end{tabular}

Means followed by the same uppercase letter in the line (Tukey 0.05) and lowercase letters in the column (Scott-Knott 0.05), do not differ for each variable.

At the low level of $\mathrm{P}$, the highest plant height mean values of physic nut plants were provided by genotypes Paraíso, CNPAE-C2 and Jales; at the high level of $\mathrm{P}$ in the soil, the highest plant height mean value was obtained by genotype CNPAE-C2 (Table 2).

For stem diameter analysis at the highest P level, genotypes 1501, 167, 315, and 210 represented the first mean group, which was statistically superior to the other mean groups. At the inferior level of P, genotype 315 was superior to the other physic nut genotypes (Table 2).

At both levels of $\mathrm{P}$ in the soil, seven distinct groups of leaf area means were formed, showing a differential response of the genotypes to phosphoric fertilization. At the low level of $\mathrm{P}$ in the soil, the high LA mean group was composed by genotype 315, and the low LA group by genotype G2. At the high level of available P, genotype Paraíso obtained a higher LA mean, being placed in the high mean group, while genotypes G2 and 08001 composed the low LA mean group (Table 2).

According to Fageria (1989), there are differences in the vegetative growth for plants of the same species, subjected to the same level of fertilization, due to the natural genetic variability, resulting in different degrees of nutritional requirements.

Studying genetic parameters of 110 physic nut accesses, Laviola et al. (2010) reported the existence of genetic variability among the genotypes. Laviola et al. (2011) studied 175 accesses, with phenotypic variability being found in the first year of implementation. Thus, the results of this study can be justified based on the genetic and phenotypic variability found by Laviola et al. (2010) and Laviola et al. (2011) physic nut accesses.

Studying bean genotypes, Lana et al. (2006) also found a differentiated vegetative growth at the same level of P in the soil. In addition to the genetic variability, these authors also justified such difference due to the fact that 
responsiveness to P supply was distinct at the initial phase of the vegetative growth, what may have occurred in this study.

Table 2 shows that genotypes 315 and Jales formed the group statistically superior, to the other mean groups, obtaining greater root volume when grown in soil with low P level, whereas genotypes $08001, \mathrm{G} 2$, and 167 presented low root volume, being placed in the low mean group. At the high P level in the soil, genotypes G2, 1501, 167 , and 200 presented a high root development, forming the first group statistically higher than the others, and genotypes 08001 and Jales, forming the lowest RV group.

Root system volume and root dry matter mass are important variables used to elucidate the mechanisms linked to phosphorus absorption efficiency (Teo et al., 1995), since root growth is inhibited under P deficiency, resulting in a reduced partition of carbohydrates allocated to the roots, indicated by an increase in the amount of sucrose (Marschner, 1995).

\subsection{Production of Dry Matter of Physic Nut Genotypes}

Table 3 shows statistical difference in dry matter production of the areal part forming seven distinct mean groups, at both levels of $\mathrm{P}$ available in the soil. According to Machado et al. (2004), this fact is connected to the difference in the capacity to respond to fertilization by the plants, due to their genetic variability.

Table 3. Production of aerial dry matter (ADM) and root dry matter (RDM) of physic nut genotypes, cultivated at two levels of phosphorus in the soil, $\left(10\right.$ and $60 \mathrm{mg} \mathrm{dm}^{-3}$, respectively, $\mathrm{P}_{1}$ and $\left.\mathrm{P}_{2}\right)$

\begin{tabular}{ccccc}
\hline \multirow{2}{*}{ Genotypes } & \multicolumn{2}{c}{ ADM } & \multicolumn{2}{c}{ RDM } \\
& $\mathrm{P}_{1}$ & $\mathrm{P}_{2}$ & $\mathrm{P}_{1}$ & $\mathrm{P}_{2}$ \\
\hline $\mathrm{G} 2$ & $41.55 \mathrm{c} \mathrm{A}$ & $40.48 \mathrm{~g} \mathrm{~A}$ & $19.44 \mathrm{c} \mathrm{A}$ & $17.15 \mathrm{e} \mathrm{B}$ \\
1501 & $40.20 \mathrm{~d} \mathrm{~B}$ & $45.52 \mathrm{dA}$ & $17.05 \mathrm{~d} \mathrm{~B}$ & $21.77 \mathrm{~b} \mathrm{~A}$ \\
167 & $34.01 \mathrm{f} \mathrm{B}$ & $41.87 \mathrm{fA}$ & $11.33 \mathrm{~g} \mathrm{~B}$ & $20.32 \mathrm{c} \mathrm{A}$ \\
315 & $41.49 \mathrm{c} \mathrm{B}$ & $49.17 \mathrm{c} \mathrm{A}$ & $22.84 \mathrm{aA}$ & $22.04 \mathrm{~b} \mathrm{~A}$ \\
210 & $38.58 \mathrm{e} \mathrm{B}$ & $45.85 \mathrm{~d} \mathrm{~A}$ & $17.25 \mathrm{~d} \mathrm{~B}$ & $18.79 \mathrm{~d} \mathrm{~A}$ \\
200 & $45.62 \mathrm{~b} \mathrm{~A}$ & $44.35 \mathrm{eA}$ & $20.77 \mathrm{~b} \mathrm{~B}$ & $24.67 \mathrm{aA}$ \\
08001 & $32.53 \mathrm{~g} \mathrm{~B}$ & $48.80 \mathrm{c} \mathrm{A}$ & $15.30 \mathrm{fA}$ & $11.26 \mathrm{fB}$ \\
Paraíso & $47.63 \mathrm{a} \mathrm{B}$ & $54.67 \mathrm{~b} \mathrm{~A}$ & $17.50 \mathrm{~d} \mathrm{~B}$ & $21.49 \mathrm{~b} \mathrm{~A}$ \\
CNPAE-C2 & $40.02 \mathrm{~d} \mathrm{~B}$ & $57.38 \mathrm{aA}$ & $19.22 \mathrm{c} \mathrm{A}$ & $20.83 \mathrm{c} \mathrm{A}$ \\
Jales & $40.75 \mathrm{c} \mathrm{B}$ & $48.79 \mathrm{c} \mathrm{A}$ & $16.15 \mathrm{e} \mathrm{B}$ & $21.56 \mathrm{~b} \mathrm{~A}$ \\
\hline
\end{tabular}

Means followed by same uppercase letter in the line (Tukey test 0.05 ) and lowercase in the column (Scott-Knott 0.05), do not differ for each variable.

It can be seen that, at the low level of $\mathrm{P}$ in the soil, Paradise genotype presented a higher aerial part dry matter (ADM) production, showing adaptation to environments with P deficiency, in contrast to genotype 08001, which had the lowest ADM mean value. At the high level of P, genotype CNPAE-C2 stood out due to its high ADM mean value, while genotype G2 showed low ADM accumulation capacity (Table 3).

Genotypes 315 and 200 obtained high RDM values, respectively, at the low and high level of $\mathrm{P}$ in the soil. For the variable root dry matter, genotypes 167 and 08001 were inferior to the others, respectively, at the low and high levels of $\mathrm{P}$ in the soil (Table 3).

Similar results have been related in studies using others oil plant species. Rogério et al. (2013) found that crambe cultivars differed in grain yield when grown under different levels of $\mathrm{P}$, occurring smaller amplitudes when a appropriate level of this element was supply for the plants.

\subsection{Content of the Phosphorus in Physic Nut Genotypes Cultivated in Levels of P}

At the low level of $\mathrm{P}$ in the soil, genotype Paraíso obtained the highest $\mathrm{P}$ content in the aerial part, unlike genotypes $167,315,210,200$, and 08001 , which formed the low mean group, presenting low phosphorus content. At the high level of P, genotype CNPAE-C2 accumulated higher P content in the aerial part, with different responses among the genotypes, due to phosphoric fertilization. Genotype 08001 composed the mean group with the lowest $\mathrm{P}$ 
content in the aerial part, indicating a greater heterogeneity of responses due to the increase in phosphoric fertilization (Table 4).

Table 4. Content of the aerial part (AP), root (R) and total phosphorus in physic nut genotypes cultivated under two levels of $\mathrm{P}\left(10\right.$ and $60 \mathrm{mg} \mathrm{dm}^{-3}$, respectively, $\mathrm{P}_{1}$ and $\left.\mathrm{P}_{2}\right)$

\begin{tabular}{|c|c|c|c|c|c|c|}
\hline \multirow{2}{*}{ Genotypes } & \multicolumn{2}{|c|}{ AP } & \multicolumn{2}{|c|}{$\mathrm{R}$} & \multicolumn{2}{|c|}{ Total } \\
\hline & $\mathrm{P}_{1}$ & $\mathrm{P}_{2}$ & $\mathrm{P}_{1}$ & $\mathrm{P}_{2}$ & $\mathrm{P}_{1}$ & $\mathrm{P}_{2}$ \\
\hline G2 & $58.25 \mathrm{~b} \mathrm{~B}$ & $85.50 \mathrm{c} \mathrm{A}$ & $17.00 \mathrm{c} \mathrm{B}$ & $34.50 \mathrm{~b} \mathrm{~A}$ & $83.00 \mathrm{~b} \mathrm{~B}$ & $119.75 \mathrm{~d} \mathrm{~A}$ \\
\hline 1501 & 59.25 b B & $95.75 \mathrm{~b} \mathrm{~A}$ & $18.25 \mathrm{c} \mathrm{B}$ & $41.00 \mathrm{aA}$ & $83.25 \mathrm{~b} \mathrm{~B}$ & $136.75 \mathrm{~b} \mathrm{~A}$ \\
\hline 167 & $55.25 \mathrm{c} \mathrm{B}$ & $93.25 \mathrm{~b} \mathrm{~A}$ & $21.25 \mathrm{~b} \mathrm{~B}$ & $37.50 \mathrm{~b} \mathrm{~A}$ & $72.25 \mathrm{c} \mathrm{B}$ & $130.75 \mathrm{c} \mathrm{A}$ \\
\hline 315 & $54.00 \mathrm{c} \mathrm{B}$ & $85.75 \mathrm{c} \mathrm{A}$ & $21.50 \mathrm{~b} \mathrm{~B}$ & $42.50 \mathrm{aA}$ & $79.25 \mathrm{c} \mathrm{B}$ & $128.25 \mathrm{c} \mathrm{A}$ \\
\hline 210 & $51.50 \mathrm{c} \mathrm{B}$ & $85.00 \mathrm{c} \mathrm{A}$ & $22.75 \mathrm{a} \mathrm{B}$ & $35.50 \mathrm{~b} \mathrm{~A}$ & $73.00 \mathrm{c} \mathrm{B}$ & $120.75 \mathrm{~d} \mathrm{~A}$ \\
\hline 200 & $62.75 \mathrm{~b} \mathrm{~B}$ & $82.25 \mathrm{c} \mathrm{A}$ & $23.00 \mathrm{a} \mathrm{B}$ & $41.25 \mathrm{aA}$ & $85.25 \mathrm{~b} \mathrm{~B}$ & $123.50 \mathrm{~d} \mathrm{~A}$ \\
\hline 08001 & $50.25 \mathrm{c} \mathrm{B}$ & $61.50 \mathrm{~d} A$ & $23.75 \mathrm{aA}$ & $19.25 \mathrm{c} \mathrm{A}$ & $71.75 \mathrm{c} \mathrm{B}$ & 80.75 e $\mathrm{A}$ \\
\hline Paraíso & $71.25 \mathrm{a} \mathrm{B}$ & $92.25 \mathrm{~b} \mathrm{~A}$ & $24.75 \mathrm{a} B$ & $42.25 \mathrm{aA}$ & $94.25 \mathrm{a} \mathrm{B}$ & $134.75 \mathrm{~b} \mathrm{~A}$ \\
\hline CNPAE-C2 & $60.75 \mathrm{~b} \mathrm{~B}$ & $108.0 \mathrm{aA}$ & $25.00 \mathrm{a} \mathrm{B}$ & $36.50 \mathrm{~b} \mathrm{~A}$ & 88.00 b B & $144.25 \mathrm{aA}$ \\
\hline Jales & $54.25 \mathrm{c} \mathrm{B}$ & $88.00 \mathrm{c} \mathrm{A}$ & $27.50 \mathrm{a} \mathrm{B}$ & $40.00 \mathrm{aA}$ & $72.50 \mathrm{c} \mathrm{B}$ & $128.00 \mathrm{c} \mathrm{A}$ \\
\hline
\end{tabular}

Means followed by the same uppercase letters in the line (Tukey test 0.05) and lowercase letters in the column (Scott-Knott 0.05), do not differ for each variable.

Genotypes Paraíso and CNPAE-C2 had a high P content in the aerial part, probably due to their higher ADM means (Table 3), a feature that elucidates genotypes which are efficient in absorbing and utilizing nutrients (Fageria, 1989).

At the low level of P available in the soil, genotypes 210, 200, 08001, Paraíso, CNPAE-C2, and Jales were placed in the superior mean group, presenting a high $\mathrm{P}$ content in the roots. For the same variable, at the high level of $\mathrm{P}$ available in the soil, genotypes 1501, 315, 200, Paraíso, and Jales showed an effective potential for P accumulation, with the last three standing out at both levels of $\mathrm{P}$ available in the soil (Table 4).

For total phosphorus content, genotypes Paraíso and CNPAE-C2 presented superior means at levels 10 and $60 \mathrm{mg}$ $\mathrm{dm}^{-3}$ of available $\mathrm{P}$ in the soil, respectively. Genotype 8001 was allocated in the lowest mean groups at both levels (Table 4).

Evaluation of genotypes using the content of $\mathrm{P}$ accumulated by the plant is positively correlated with the mechanisms responsible for the greater efficiency of nutrient translocation (Machado et al., 2004).

\subsection{Nutritional Efficiency of P in Physic Nut}

Table 5 shows that the increase in the level of $\mathrm{P}$ available in the soil maximized the absorption efficiency of the physic nut genotypes. Such result may be explained by the fact that an adequate supply of $P$ in the soil favors root growth (Novais et al., 2007), increases the absorption, and, later, the content of $\mathrm{P}$ in the plant tissues (Malavolta, 2006), leading to the optimization of phosphorus AE, due to the variables used in this index (Swiader et al., 1994).

At a low P level in the soil, genotypes 167 and Paraíso presented high phosphorus AE, contrary to genotypes G2, 315 and 200, which were placed in the low AE mean group. At the high P level, the group formed by genotypes G2, 08001, and CNPAE-C2 had higher phosphorus AE mean values, while genotype 200 showed lower AE (Table 5).

According to Lana et al. (2006), plants efficient in P absorption are those that accumulate higher amounts of the element when grown under low P level; however, this aspect does not necessarily make them responsive to phosphoric fertilization.

Genotypes 1501, 167, 200, Paraíso and Jales presented a higher TE at the low level of available phosphorus in the soil (Table 5) due to the fact that most of the total P content is in the aerial part of the physic nut plants (Table 4), On the other hand, genotype 315 presented a low TE value (Table 5), justified by the low P content in the aerial part, and considerable $\mathrm{P}$ content in the roots, characteristics inversely correlated to nutrient translocation efficiency (Fageria, 1998). 
Table 5. Absorption efficiency (AE), translocation efficiency (TE) and utilization efficiency (UE) of physic nut genotypes, cultivated at two levels of phosphorus available in the soil, 10 and $60 \mathrm{mg} \mathrm{dm}^{-3}$, respectively, $\mathrm{P}_{1}$ and $\mathrm{P}_{2}$

\begin{tabular}{|c|c|c|c|c|c|c|}
\hline \multirow{2}{*}{ Genotypes } & \multicolumn{2}{|c|}{$\mathrm{AE}$} & \multicolumn{2}{|c|}{ TE } & \multicolumn{2}{|c|}{ UE } \\
\hline & $\mathrm{P}_{1}$ & $\mathrm{P}_{2}$ & $\mathrm{P}_{1}$ & $\mathrm{P}_{2}$ & $\mathrm{P}_{1}$ & $\mathrm{P}_{2}$ \\
\hline G2 & $4.00 \mathrm{c} \mathrm{B}$ & $7.00 \mathrm{aA}$ & $68.00 \mathrm{~b} \mathrm{~B}$ & $71.00 \mathrm{c} \mathrm{A}$ & $45.00 \mathrm{~b} \mathrm{~A}$ & $27.75 \mathrm{~d} \mathrm{~B}$ \\
\hline 1501 & $4.75 \mathrm{~b} \mathrm{~B}$ & $6.25 \mathrm{c} \mathrm{A}$ & $70.25 \mathrm{aA}$ & 67.50 e $B$ & 39.50 с A & $33.00 \mathrm{c} \mathrm{B}$ \\
\hline 167 & 5.75 a B & $6.50 \mathrm{~b} \mathrm{~A}$ & $74.00 \mathrm{aA}$ & 67.50 e $\mathrm{B}$ & $32.25 \mathrm{~d} \mathrm{~A}$ & $29.50 \mathrm{~d} \mathrm{~B}$ \\
\hline 315 & $3.50 \mathrm{c} \mathrm{B}$ & $6.00 \mathrm{c} \mathrm{A}$ & $64.25 \mathrm{c} \mathrm{B}$ & $69.00 \mathrm{~d} A$ & $52.25 \mathrm{aA}$ & $39.50 \mathrm{~b} \mathrm{~B}$ \\
\hline 210 & $4.50 \mathrm{~b} \mathrm{~B}$ & $6.50 \mathrm{~b} \mathrm{~A}$ & $69.00 \mathrm{~b} \mathrm{~B}$ & $71.00 \mathrm{c} \mathrm{A}$ & $43.00 \mathrm{~b} \mathrm{~A}$ & 34.75 c B \\
\hline 200 & $4.00 \mathrm{c} \mathrm{B}$ & $5.00 \mathrm{dA}$ & $68.75 \mathrm{~b} \mathrm{~A}$ & $64.00 \mathrm{fB}$ & $51.50 \mathrm{aA}$ & $38.50 \mathrm{~b} \mathrm{~B}$ \\
\hline 08001 & $5.00 \mathrm{~b} \mathrm{~B}$ & $7.25 \mathrm{aA}$ & $68.00 \mathrm{~b} \mathrm{~B}$ & $81.00 \mathrm{aA}$ & $32.00 \mathrm{~d} \mathrm{~B}$ & $45.00 \mathrm{aA}$ \\
\hline Paraíso & $5.25 \mathrm{a} \mathrm{B}$ & $6.25 \mathrm{c} \mathrm{A}$ & $73.00 \mathrm{aA}$ & $71.50 \mathrm{c} \mathrm{B}$ & $45.00 \mathrm{~b} \mathrm{~A}$ & $43.00 \mathrm{a} \mathrm{B}$ \\
\hline CNPAE-C2 & $4.75 \mathrm{~b} \mathrm{~B}$ & $7.00 \mathrm{aA}$ & $67.50 \mathrm{~b} \mathrm{~B}$ & $73.25 \mathrm{~b} \mathrm{~A}$ & $40.00 \mathrm{c} \mathrm{B}$ & $42.50 \mathrm{aA}$ \\
\hline Jales & $4.50 \mathrm{~b} \mathrm{~B}$ & $6.00 \mathrm{c} \mathrm{A}$ & $71.50 \mathrm{aA}$ & $69.00 \mathrm{~d} \mathrm{~B}$ & $44.50 \mathrm{~b} \mathrm{~A}$ & $38.75 \mathrm{~b} \mathrm{~B}$ \\
\hline
\end{tabular}

Means followed by the same uppercase letters in the line (Tukey 0.05) and lowercase letters in the column (Scott-Knott 0.05), do not differ for each variable.

There was high TE variability at the high level of $\mathrm{P}$ in the soil, confirmed by the formation of six distinct mean groups, with genotype 08001 presenting the highest TE and genotype 200 showing a reduced capacity of phosphorus translocation (Table 5).

Such large number of distinct TE mean groups is caused by the genetic variability (Laviola et al., 2010; Bhering et al., 2012) of physic nut genotypes.

The mechanisms and interactions that elucidate translocation efficiency have a complex character. In general, plants grown in environments deficient in $\mathrm{P}$ retain higher $\mathrm{P}$ content in the roots, decreasing nutrient translocation from the roots to the photo-synthetically active sites in the leaves. Another determinant TE factor is the genotype's respiration rate (Taiz \& Zeiger, 2006).

The physic nut genotypes obtained greater utilization efficiency (UE) of $\mathrm{P}$ at the low level of $\mathrm{P}$ available in the soil, except for genotypes CNPAE-C2 and 08001 (Table 5).

Although dry matter and content of $\mathrm{P}$ in the aerial part and root were higher at the high level of $\mathrm{P}$ available in the soil (Tables 3 and 4), the amplitude between these variables is small, i.e., the gain of dry matter mass and P content at the low level of $\mathrm{P}$ in the soil is high, rendering the plants more efficient in phosphorus utilization at the low level of this nutrient in the soil.

These results allow the possibility of developing cultivars for marginal fertility areas, aiming at reducing the use of fertilizers, since UE has a direct relationship with the ability of a genotype to accumulate dry matter with minimum possible nutrient investment (Amaral et al., 2011).

Table 5 shows that at the low level of available phosphorus in the soil, genotypes 315 and 200 are allocated at the high mean group, presenting phosphorus-use efficiency. This is because these genotypes showed high dry matter values and low P content means (Tables 3 and 4), contrary to genotypes 167 and 08001 , which presented low P-use efficiency.

At the high level of phosphorus available in the soil, genotypes Paraíso, CNPAE-C2, and 08001 were efficient in P use, while genotypes G2 and 167 had low UE (Table 5).

Genotypes Paraíso and CNPAE-C2 showed a high dry matter value as well as high total phosphorus content values (Table 3 and 4), maximizing their utilization efficiency index, unlike genotype 08001, which presented low dry matter and P content (Table 3 and 4), but also obtained maximized EU at the high level of $\mathrm{P}$ in the soil (Table 5).

According to Fageria (1998), P utilization efficiency index is an important physiological component in the selection of genotypes tolerant to low $\mathrm{P}$ availability in the soil, and differences in biomass production under low $\mathrm{P}$ are associated with utilization efficiency, confirming the results of this study. 


\subsection{Efficiency and Responsiveness of Physic nut to $P$}

Figure 1 shows the efficiency and responsiveness of the physic nut genotypes in relation to the level of $P$ available in the soil, based on the concept proposed by Ciat (1978).

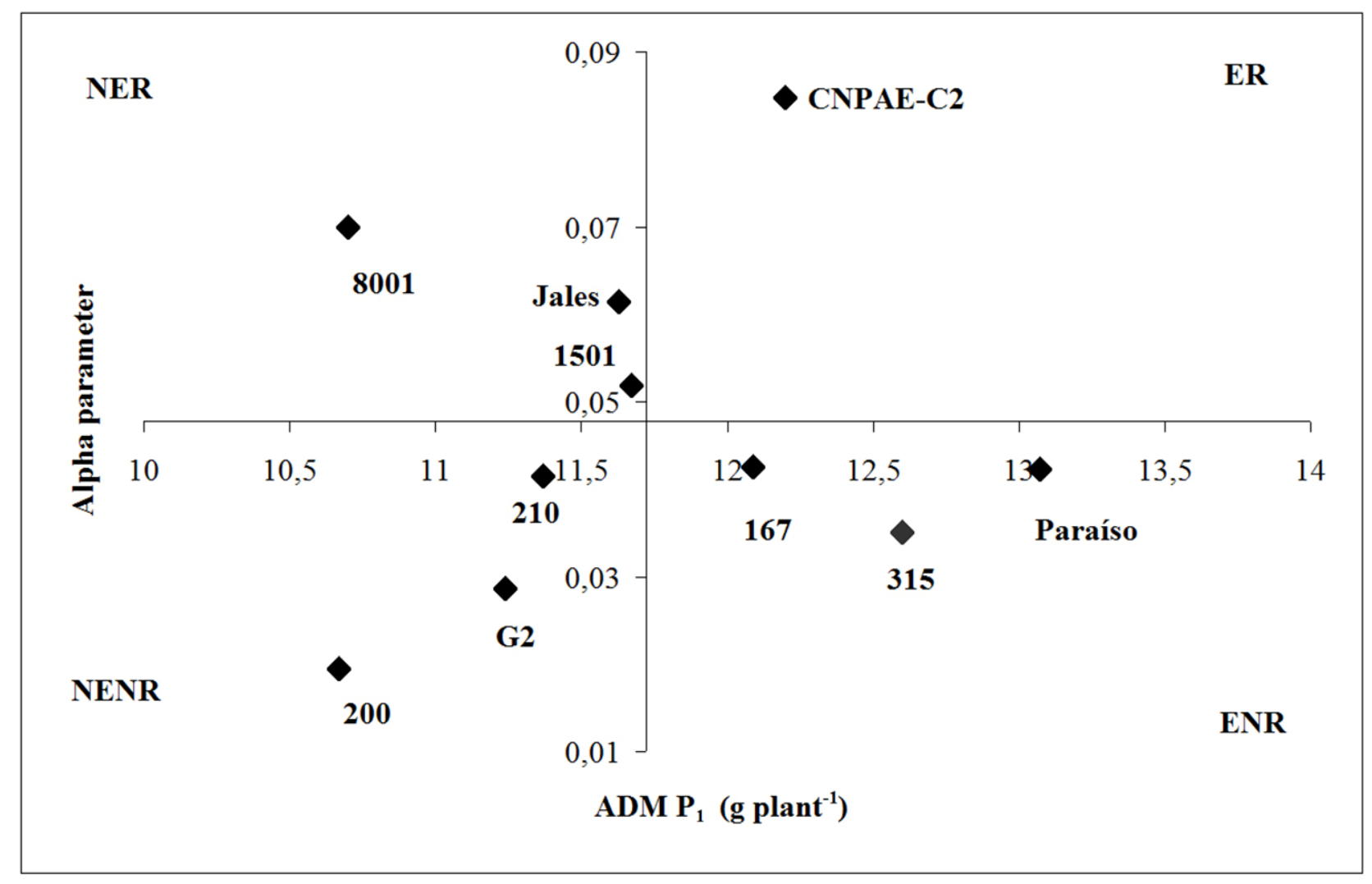

Figure 1. Classification of physic nut genotypes for efficiency and responsiveness to available $\mathrm{P}$ in the soil

Only genotype CNPAE-C2 stood out as efficient and responsive (ER) following higher ADM accumulation under low P level conditions, in response to increased availability of this nutrient in the soil (Figure 1).

For a genotype to be efficient and responsive to phosphorus fertilization, it must have favorable characteristics, such as $\mathrm{P}$ translocation from the roots to the growing tissues, remobilization of nutrients from senescent leaves prior to abscission, and an adequate reproductive development so that the largest possible amount of $\mathrm{P}$ can be used to produce seeds (Marschner, 1995).

Genotypes 315, 167, and Paraíso were classified as efficient and non-responsive (ENR), assuming that although they produced significantly at the low $\mathrm{P}$ level, their response to $\mathrm{P}$ available in the soil was lower (Figure 1).

Genotypes Jales, 08001, and 1501 were classified as non efficient and responsive (NER), since, although responding to $\mathrm{P}$ availability in the soil, their dry matter production was not the same achieved by genotypes classified as ER and ENR, at the low level of phosphorus (Figure 1).

Finally, genotypes 200, 210, and G2 were classified as non efficient and non responsive (NENR), due to their low aerial part dry matter production, under increased levels of available $P$ in the soil (Figure 1).

\section{Conclusions}

Physic nut genotypes have greater vegetative growth, dry matter accumulation, $\mathrm{P}$ content and absorption and translocation efficiency at the high level of phosphorus available in the soil.

Physic nut genotypes present different responses at each level of phosphoric fertilization.

Genotype CNPAE-C2 is the most efficient and responsive to phosphoric fertilization. 


\section{References}

Amaral, J. F. T., Martinez, H. E. P., Laviola, B. G., Fernandes Filho, E. I., \& Cruz, C. D. (2011). Eficiência de utilização de nutrients por cultivares de cafeeiro. Ciência Rural., 41, 621-629. http://dx.doi.org/10.1590/S0103-84782011005000027

Bhering, L. L., Barrera, C. F., Ortega, D., Laviola, B. G., Alves, A. A., Rosado, T. B., \& Cruz, C. D. (2012). Differential response of Jatropha genotypes to different selection methods indicates that combined selection is more suited than other methods for rapid improvement of the species. Industrial Crops and Products, 41, 260-265.

Ciat, Centro Internacional de Agricultura Tropical. (1978). Cali, Colombia, Programa de frijol. Informativi Annual 1978 (pp. 12-13). Cali, Colombia.

Embrapa, Empresa Brasileira de Pesquisa Agropecuária. (2006). Centro Nacional de Pesquisa de Solos. Sistema brasileiro de classificação de solos (p. 306). 2. ed. Rio de Janeiro.

Embrapa, Empresa Brasileira de Pesquisa Agropecuária. (1997). Manual de métodos de análises de solo (p. 212). 2.ed. Rio de Janeiro, Ministério da Agricultura e do Abastecimento.

Fageria, N. K. (1998). Otimização da eficiêncianutricionalnaprodução das culturas. Revista Brasileira de Engenharia Agricola e Ambiental, 2, 6-16.

Fageria, N. K., \& Baligar, V. C. (1997). Phosphorus-use efficiency by corn genotypes. Journal of lant Nutrition, 20, 1267-1277.

Falasca, S. L., Flores, N., Lamas, M. C., Carballo, S. M., \& Anschau, A. (2010). Crambeabyssinica: An almost unknown crop with a promissory future to produce biodiesel in Argentina. International Journal of Hydrogen Energy, 35, 5808-5812. http://dx.doi.org/10.1016/j.ijhydene.2010.02.095

Ferreira, D. F. (2008). Sisvar: um programa para análises e ensino de estatística. Revista Symposium, 6, 36-41.

Lana, R. M. Q., Zanão, L. A., Correia, N. M., \& Lana, A. M. Q. (2006). Variabilidade entre genótipos de feijoeiro na eficiência no uso do fósforo. Ciência Rural, 36, 778-784. http://dx.doi.org/10.1590/S0103-84782006000300009

Laviola, B. G., Bhering, L. L., Mendonca, S., Rosado, T. B., \& Albrecht, J. C. (2011). Caracterização morfo-agronômica do banco de germoplasma de pinhão-manso na fase jovem. Bioscience Journal, 27, 371-379. http://dx.doi.org/10.1590/S0100-204X2010001000010

Laviola, B. G., \& Dias, L. A. S. (2008). Teor e acúmulo de nutrientes em folhas e frutos de pinhão-manso. $\begin{array}{lllll}\text { Revista Brasileira de Ciencia do Solo, } & 32, & \text { 1969-1975. }\end{array}$ http://dx.doi.org/10.1590/S0100-06832008000500018

Laviola, B. G., Rosado, T. B., Bhering, L. L., Kobayashi, A. K., \& Resende, M. D. V. (2010). Genetic parameters and variability in physic nut accessions during early developmental stages. Pesquisa Agropecuária Brasileira, 45, 1117-1123.

Li, B., McKeand, S. E., \& Allen, H. L. (1991). Genetic variation in nitrogen use efficiency of loblolly pine seedlings. Forest Science, 37(2), 613-626.

Machado, C. T. T., Furlani, A. C., \& Machado, A. T. (2004). Índices de eficiência de variedades locais e melhoradas de milho ao fósforo. Bragantia, 60(3), 225-238. http://dx.doi.org/10.1590/S0006-87052001000300010

Machado, V. J., Souza, C. H. E., Andrade, B. B., Lana, R. M. Q., \& Korndorfer, G. H. (2011). Curvas de disponibilidade de fósforo em solos com diferentes texturas após aplicação de doses crescentes de fosfatomonoamônico. Bioscience Journal, 27(1), 70-76.

Malavolta, E. (2006). Manual de nutrição mineral de plantas. São Paulo: Agronômica Ceres (p. 638).

Marschner, H. (1995). Mineral nutrition of higher plant (2 ed.) (p. 889). London: Academic Press.

Novais, R. F., Neves, J. C. L., \& Barros, N. F. (1991). Ensaio em ambiente controlado. In A. J. Oliveira, W. E. Garrido, J. D. Araújo, S. Lourenço (Eds.). Métodos de pesquisa em fertilidade do solo (pp.189-254). Brasília: Embrapa/Sae.

Novais, R. F., Smyth, T. J., \& Nunes, F. N. (2007). Fósforo. In R. F. Novais, V. H. Alvarez, N. F. Barros, R. L. F. Fontes, R. B. Cantarutti, J. C. L. NEVES (Eds.). Fertilidade do solo (pp. 471-550). Viçosa: Sociedade Brasileira de Ciência de Solo. 
Oladiran, O., Olajire, F., Robert, C. A., \& Nnenna, I. (2012). Phosphorus response efficiency in cowpea genotypes. Journal of Agricultural Science, 4(1), 81-90.

Raij, B. V., Andrade, J. C., Cantarella, H., \& Quaggio, J. A. (2001). Análise química para avaliação da fertilidade de solos tropicais (Ed.) (p.284). Campinas: Instituto Agronômico.

Reis, T. H. P., Furtini Neto, A. E., Guimarães, P. T. G., Curi, N., Guerra, A. F., \& Marques, J. J. (2011). Dynamics of forms of inorganic phosphorus in soil under coffee plants as a function of successive annual additions of the nutrient. Communications in Soil Science and Plant Analysis, 42(3), 980-991. http://dx.doi.org/10.1080/00103624.2011.558966

Reis, T. H. P., Guimarães, P. T. G., Furtini Neto, A. E., Guerra, A. F., \& Curi, N. (2010). Soil phosphorus dynamics and availability and irrigated coffee yield. Revista Brasileira de Ciência do Solo (Impresso), 35(1), 503-512.

Resende, Á. V., Furtini Neto, A. E., Alves, V. M. C., Curi, N., Muniz, J. A., \& Faquin, V. (2007). Phosphate efficiency for corn following brachiaria grass pasture in the cerrado region. Better crops with plant food, 91(1), 17-19.

Rogério, F., Silva, T. R. B., Santos, J. I., \& Poletine, J. P. (2013). Phosphorus fertilization influences grain yield and oil content in crambe. Industrial Crops and Products, 41(3). 266-268. http://dx.doi.org/10.1016/j.indcrop.2012.04.016

Santana, E. P., Sant'ana, E. V. P., Fageria, N. K., \& Freire, A. B. (2003). Utilização de fósforo e características do sistema radicular e da parte aérea da planta de arroz. Ciência e Agrotecnologia, 27, 370-381.

Siddiqi, M. Y., \& Glass, A. D. M. (1981). Utilization index: a modified approach to the estimation and comparison of nutrient utilization efficiency in plants. Journal of Plant Nutrition, 4(3), 289-302. http://dx.doi.org/10.1080/01904168109362919

Swiader, J. M., Chyan, Y., \& Freiji, F. G. (1994). Genotypic differences in nitrate uptake and utilization efficiency in pumpkin hybrids. Journal of Plant Nutrition. 17(10), 1687-1699. http://dx.doi.org/10.1080/01904169409364840

Taiz, L., Zeiger, E. (2006). Fisiologia vegetal: Artmed. p.719.

Teo, Y. H., Beyrouty, C. A., \& Gbur, E. E. (1995). Evaluation of a model to predict nutrient uptake by field-grow rice. Agronomy Journal, 87(1), 7-12. http://dx.doi.org/10.2134/agronj1995.00021962008700010002x

Wright, S. P., Yavitt, J. B., Wurzburger, N., Turner, B. B., Tanner, E. V. J., Sayer, E. J., \& Santiago, L. S. (2011) Potassium, phosphorus, or nitrogen limit root allocation, tree growth, or litter production in a lowland tropical forest. Ecology, 92(8), 1616-1625. http://dx.doi.org/10.1890/10-1558.1 